\title{
Type I nitroreductases in soil enterobacteria reduce TNT (2,4,6-trinitrotoluene) and RDX (hexahydro-1,3,5-trinitro-1,3,5-triazine)
}

\author{
Christopher L. Kitts, Chad E. Green, Rebecca A. Otley, Marc A. Alvarez, \\ and Pat J. Unkefer
}

\begin{abstract}
Many enteric bacteria express a type I oxygen-insensitive nitroreductase, which reduces nitro groups on many different nitroaromatic compounds under aerobic conditions. Enzymatic reduction of nitramines was also documented in enteric bacteria under anaerobic conditions. This study indicates that nitramine reduction in enteric bacteria is carried out by the type I, or oxygen-insensitive nitroreductase, rather than a type II enzyme. The enteric bacterium Morganella morganii strain B2 with documented hexahydro-1,3,5-trinitro-1,3,5-triazine (RDX) nitroreductase activity, and Enterobacter cloacae strain 96-3 with documented 2,4,6-trinitrotoluene (TNT) nitroreductase activity, were used here to show that the explosives TNT and RDX were both reduced by a type I nitroreductase. Morganella morganii and E. cloacae exhibited RDX and TNT nitroreductase activities in whole cell assays. Type I nitroreductase, purified from E. cloacae, oxidized NADPH with TNT or RDX as substrate. When expression of the E. cloacae type I nitroreductase gene was induced in an Escherichia coli strain carrying a plasmid, a simultaneous increase in TNT and RDX nitroreductase activities was observed. In addition, neither TNT nor RDX nitroreductase activity was detected in nitrofurazone-resistant mutants of $M$. morganii. We conclude that a type I nitroreductase present in these two enteric bacteria was responsible for the nitroreduction of both types of explosive.
\end{abstract}

Key words: nitroreductase, TNT, RDX, Enterobacter cloacae, Morganella morganii.

Résumé : Différentes bactéries entériques produisent une nitroréductase de type I insensible à l'oxygène capable de réduire les groupements nitro de divers composés nitroaromatiques dans des conditions anaérobies. La réduction enzymatique des nitramines en anaérobiose est aussi connue chez les entérobactéries. La présente étude indique que la réduction des nitramines par les entérobactéries était catalysée par une nitroréductase de type I non sensible à l'oxygène plutôt que par une enzyme de type II. La souche B2 de Morganella morganii reconnue pour son activité hexahydro-1,3,5-trinitro-1,3,5-triazine (RDX) nitroréductase, et la souche 96-3 d'Enterobacter cloacae reconnue pour son activité 2,4,6 trinitrotoluène (TNT) nitroréductase, ont toutes deux servi à démontrer que les deux explosifs TNT et RDX étaient réduits par une nitroréductase de type I. Les RDX et TNT nitroréductases de M. morganii et d'E. cloacae ont été observées lors d'essais avec des bactéries entières. La nitroréductase de type I, purifiée de l'E. cloacae, oxydait le NADPH en présence de TNT ou de RDX comme substrat. L'induction de l'expression du gène de la nitroréductase de type I de l'E. cloacae chez une souche d'Escherichia coli porteuse d'un plasmide a causé une augmentation spontanée de l'activité des TNT et RDX nitroréductases. Par contre aucune activité TNT ou RDX nitroréductase n'a été observée chez des mutants de $M$. morganii résistants au nitrofurazone. La présente étude permet de conclure que la nitroréductase de type I retrouvée chez ces deux bactéries entériques était responsable de la nitroréduction de ces deux types d'explosifs.

Mots clés : nitroréductase, TNT, RDX, Enterobacter cloacae, Morganella morganii.

[Traduit par la Rédaction]

Received July 23, 1999. Revision received November 4, 1999. Accepted November 9, 1999.

C.L. Kitts, ${ }^{\mathbf{1}}$ C.E. Green, and R.A. Otley. Environmental Biotechnology Institute, California Polytechnic State University, San Luis Obispo, CA 93407, U.S.A.

M.A. Alvarez and P.J. Unkefer. Chemical Science and Technology Division, CST-4, Los Alamos National Laboratory, Los Alamos, NM 87545, U.S.A.

${ }^{1}$ Author to whom all correspondence should be addressed (email: ckitts@calpoly.edu). 
Enzymes that are capable of reducing nitro groups on nitroaromatic compounds are called nitroreductases. These nitroreductases are unlike the assimilatory and dissimilatory nitrate/nitrite reductases as they do not reduce nitrate or nitrite, are not part of any respiratory chain, and do not provide a source of reduced nitrogen for cellular growth (Bryant and DeLuca 1991; Kinouchi and Ohnishi 1983). Nitroreductases are thought to be expressed only constitutively, and their physiological functions are unclear (Bryant et al. 1991; Einistö et al. 1991; Kinouchi and Ohnishi 1983). However, partial reduction of the nitro groups on nitroaromatic compounds, resulting in nitroso or hydroxylamine compounds, is generally accepted as the key step in activation of these compounds to potent mutagens and carcinogens (Einistö et al. 1991; Hartter 1985). The nitroreductases are classified by their relative sensitivity to $\mathrm{O}_{2}$. Oxygen insensitive, or type I nitroreductases, use a two-electron reduction mechanism, and are able to reduce nitro groups under aerobic conditions (Peterson et al. 1979; Wenzhong et al. 1987). Conversely, oxygen sensitive, or type II nitroreductases, reduce nitro groups in a single electron process, forming a nitro anion radical. In the presence of $\mathrm{O}_{2}$, the nitro anion radical may be oxidized back to a nitro group, and a superoxide anion $\left(\mathrm{O}_{2}{ }^{-}\right)$is produced (McCalla et al. 1970; Peterson et al. 1979). As long as $\mathrm{O}_{2}$ is present, a futile cycle operates, which consumes reducing equivalents through the nitroreductase without net nitro group reduction. Thus, type II nitroreductases are only capable of net nitro group reduction in anaerobic environments.

Type I nitroaromatic nitroreductases have been described in many bacteria, particularly the enterobacteria, where they are called classical nitroreductases (Brenner 1984; Bryant and DeLuca 1991; Cartwright and Cain 1959; Kinouchi and Ohnishi 1983; McCalla et al. 1970; Mori et al. 1984; Schackmann and Müller 1991; Wenzhong et al. 1987). Substrates for these enzymes range from the nitrofuran antibiotics to nitroarenes such as 1-nitropyrene, and also include nitroaromatic explosives such as 2,4,6-trinitrotoluene (TNT). The compounds most commonly observed during nitroreduction of nitroaromatics are aromatic hydroxylamines (Cartwright et al. 1959; Kaplan 1990; McCalla et al. 1970; McCormick et al. 1976; Mori et al. 1984; Schackmann and Müller 1991; Schenzle et al. 1999). However, evidence does exist for the formation of a nitroso functional group during biological reduction of some nitroaromatics (Liu et al. 1984).

An oxygen insensitive, type I nitroreductase purified from Enterobacter cloacae strain 96-3 shows a broad substrate specificity, reducing nitro groups on such diverse nitroaromatic compounds as TNT, 4-nitrophenol, 4-nitroacetophenone, and 4-nitrobenzene methyl sulfonate (Bryant and DeLuca 1991). Although reaction with these compounds occurs in the presence of oxygen, reaction rates vary by three orders of magnitude; TNT is the most rapidly reduced substrate while 4-nitrophenol is the least.

In contrast to the nitroaromatic nitroreductases, less information is available on the enzymatic reduction of nitramine nitro groups. Early studies involving the biodegradation of the nitramine explosives hexahydro-1,3,5-trinitro-1,3,5-triazine (RDX), and octahydro-1,3,5,7-tetranitro-1,3,5,7-tetrazocine (HMX), showed nitroreduction of nitramines proceeding only in anaerobic environments through the production of
Table 1. Nitroreductase activity with TNT and RDX as substrates.

\begin{tabular}{lll}
\hline Substrate & $\begin{array}{l}\text { M. morganii } \\
\text { strain B2 }\end{array}$ & $\begin{array}{l}\text { E. cloacae } \\
\text { strain 96-3 }\end{array}$ \\
\hline TNT & $46.5(2.8)^{a}$ & $42.2(3.8)^{a}$ \\
RDX & $0.010(0.001)^{b}$ & $0.014(0.003)^{b}$ \\
TNT/RDX (activity ratio) & $4649 \pm 753$ & $3014 \pm 962$ \\
\hline \multicolumn{1}{c}{${ }^{a}$ Rate of TNT nitroreduction as $^{b}$ measured with a whole cell suspension }
\end{tabular}

${ }^{a}$ Rate of TNT nitroreduction as measured with a whole cell suspension. Units are nmol (TNT lost) $\cdot \mathrm{min}^{-1} \cdot \mathrm{mg}^{-1}$ protein; standard deviation of three parallel experiments is included in parentheses.

${ }^{b}$ Rate of RDX nitroreduction in cell culture during the first 4 days of incubation. Units are $\mathrm{nmol}\left(\mathrm{RDX}\right.$ lost) $\cdot \mathrm{min}^{-1} \cdot \mathrm{mg}^{-1}$ protein; standard deviation of three parallel experiments is included in parentheses.

stable nitroso intermediates (McCormick et al. 1984; Spanggord et al. 1983). This suggests that type I nitroreductases may not be involved in the biological nitroreduction of nitramines. However, these studies were performed using mixed bacterial cultures, making it difficult to evaluate specific enzyme activities. More recent studies indicate that aerobic RDX degradation does occur, but not through the reduction of RDX to produce the nitroso intermediates (Binks et al. 1995; Coleman et al. 1998).

We previously isolated an enteric bacterium from explosives-contaminated soil (Morganella morganii strain B2 (Kitts et al. 1994)) which was capable of reducing the nitro groups on both RDX and TNT (Kitts et al. 1994). Another soil-isolated enteric bacterium (Enterobacter cloacae strain 96-3 (ATCC 43560)) was also able to reduce the nitro groups on both explosives. Aerobic cultures of M. morganii and $E$. cloacae reduced measurable amounts of TNT in vivo, but did not reduce measurable amounts of RDX. This led us to the hypothesis that a type II nitroreductase activity might reduce RDX. However, as we show in this study, a type I nitroreductase activity is responsible for reducing the nitro groups on both nitramine (RDX) and nitroaromatic (TNT) explosives in these organisms.

Morganella morganii strain B2, and E. cloacae strain 96-3 reduced nitro groups on both RDX and TNT in whole cell assays. Because the rate of RDX nitroreduction was very low, assays of RDX nitroreductase activity were followed for several days using cultures grown in YE medium (minimal salts from Beardsmore (1982) plus $0.8 \%$ yeast extract). RDX concentrations in the growth medium were at $0.3 \mathrm{mM}$, and were assayed during the first four days of incubation using HPLC as described previously (Kitts et al. 1994). During this time, RDX concentrations decreased at linear rates in all the cultures tested, and the cell density (as measured by $\left.A_{600}\right)$ did not change appreciably after reaching the stationary phase in the first $8 \mathrm{~h}$. Uninoculated media with RDX did not lose appreciable amounts of the explosive during this time. Conversely, TNT nitroreductase activity was very high, and could be rapidly measured in whole cell suspensions. Cultures of bacteria grown in YE medium were harvested by centrifugation, and washed once with $40 \mathrm{mM}$ phosphate buffer ( $\mathrm{pH} 7)$. The cells were resuspended in $5.0 \mathrm{~mL}$ of phosphate buffer saturated with TNT. During incubation at $30^{\circ} \mathrm{C}$, aliquots were removed, and concentrations of TNT were determined using high performance liquid chromatography (HPLC) as described previously (Alvarez et al. 1995). 
In both cases, a standard curve of $A_{600}$ to cell dry weight was obtained, and an estimation of the fraction of protein to dry cell weight (55\%; Ingram et al. 1983) was used to produce a specific activity relative to cell protein. Chromatograms from both strains with both substrates showed the appropriate compounds present to indicate that reduction of the nitro groups was occurring as seen previously (Bryant and DeLuca 1991; Kitts et al. 1994). A comparison between nitroreductase substrates, TNT and RDX, indicated a 4000-fold difference in rate for the activities in M. morganii strain B2 (Table 1). Enterobacter cloacae strain 96-3 was also able to reduce the nitro groups on RDX in restricted aeration cultures at rates about 3000 times slower than for TNT. Thus, both strains exhibit a similar ratio of TNT to RDX nitroreductase rates.

Purified E. cloacae type I nitroreductase oxidized NADPH with either RDX or TNT as substrate. Purified type I nitroreductase from E. cloacae was generously supplied to us by Anne Francis Miller at Johns Hopkins University. TNT nitroreductase assays were performed in a dual beam spectrophotometer (Jasco V-560) with 1-mL quartz cuvettes. The sample and reference cuvettes contained $10 \mathrm{mM}$ Tris buffer (pH 8.0), $1 \mathrm{mM} \mathrm{MgCl} 2,1 \mathrm{mM} \mathrm{NADPH}$ (Sigma) and $3 \mu \mathrm{L}$ of purified enzyme. The sample cuvette also contained $0.4 \mathrm{mM}$ TNT. Nitroreductase activity was measured as a decrease in $A_{340}$, indicating a TNT-dependent oxidation of NADPH. Rates were calculated using a molar extinction coefficient for NADPH of $6220 A_{340} \cdot \mathrm{cm}^{-2}$. The RDX nitroreductase activity of this purified enzyme was also assayed by following NADPH oxidation with $100 \mu \mathrm{L}$ of enzyme solution in a cuvette with the same buffer system as the TNT assay above, except using $0.3 \mathrm{mM}$ RDX. Disappearance of RDX from this assay system was verified using HPLC. The specific activity of the purified enzyme was $1.05 \times 10^{5} \mathrm{nmol}$ (NADPH oxidized) $\cdot \mathrm{min}^{-1} \cdot \mathrm{mg}^{-1}$ protein with TNT, and $68.7 \mathrm{nmol}$ (NADPH oxidized) $\cdot \mathrm{min}^{-1} \cdot \mathrm{mg}^{-1}$ protein with RDX as substrate. Thus the rate with RDX as a substrate was about 1500 times less than with TNT as a substrate; a ratio on the same order of magnitude as was seen with the whole cell assays.

Expression of the Enterobacter cloacae nitroreductase gene from an $E$. coli plasmid resulted in simultaneous increases in RDX and TNT nitroreductase activities. Enterobacter cloacae strain 96-3 was the source of a type I nitroreductase gene cloned into $E$. coli strain TB1. Strain TB1 contains a two-plasmid expression system designed to express high levels of E. cloacae nitroreductase (Bryant et al. 1991). The expression of the cloned E. cloacae nitroreductase gene is induced by a shift in growth temperature from $30^{\circ} \mathrm{C}$ to $42^{\circ} \mathrm{C}$ (Tabor et al. 1985 ; Bryant and DeLuca 1991; Bryant et al. 1991). Induced (heat shocked) and uninduced cultures of TB1 were tested for TNT nitroreductase activity and RDX nitroreductase activity. Cultures tested for TNT nitroreductase activity were grown overnight in $30 \mathrm{~mL}$ of $\mathrm{YE}$ (plus $50 \mathrm{mg} \cdot \mathrm{L}^{-1}$ kanamycin and $100 \mathrm{mg} \cdot \mathrm{L}^{-1}$ ampicillin), harvested by centrifugation, and washed once with phosphate buffer. The cells were resuspended in $1.5 \mathrm{~mL}$ of phosphate buffer, and frozen at $-70^{\circ} \mathrm{C}$ until time for assay. Frozen cells were thawed on ice and disrupted by sonication with a microprobe at a power set-
Table 2. Nitroreductase activity in E. coli strain TB1with TNT and RDX as substrates.

\begin{tabular}{lcl}
\hline E. coli strain TB1 & $\mathrm{TNT}^{a}$ & $\mathrm{RDX}^{b}$ \\
\hline Uninduced $^{c}$ & $182(18)$ & $0.006(0.001)$ \\
Induced $^{c}$ & $1301(105)$ & $0.030(0.004)$ \\
\hline
\end{tabular}

${ }^{a}$ Rate of TNT nitroreduction as measured by NADPH oxidation with a cell-free extract. Units are nmol (NADPH oxidized) $\mathrm{min}^{-1} \cdot \mathrm{mg}^{-1}$ protein.

Standard deviation of three parallel experiments is included in parentheses.

${ }^{b}$ Rate of RDX nitroreduction in cell culture during the first 4 days of incubation. Units are nmol (RDX lost) $\cdot \mathrm{min}^{-1} \cdot \mathrm{mg}^{-1}$ protein. Standard deviation of three parallel experiments is included in parentheses.

'Expression of a cloned E. cloacae type I nitroreductase gene was induced by a $20 \mathrm{~min}$ heat shock (see Materials and methods).

ting of $2(5 \times 15$ s bursts with an Ace Glass model GE6005 sonicator). Unbroken cells were pelleted by centrifugation (30 min at $14000 \mathrm{rpm}$ ) and the cell free extract decanted to a clean tube. Two hundred microlitres of the cell free extract was used to assay NADPH oxidation in the spectrophotometric assay described above. RDX nitroreductase activity was measured as loss of RDX from whole cell assays as described above. An approximately seven-fold increase in TNT nitroreductase activity was detected in cultures subjected to the $42^{\circ} \mathrm{C}$ heat shock (Table 2). A similar increase, approximately five-fold, in RDX nitroreductase activity was detected in heat-shocked cultures. RDX nitroreductase activity was measured over a four-day period after the initial heat shock. TNT nitroreductase activity was measured about $14 \mathrm{~h}$ after the heat shock. This difference in assay procedure may explain why the heat shock produced an apparently greater increase in nitroreductase activity with TNT as substrate compared with RDX as substrate. However, it is clear that induction of the E. cloacae type I nitroreductase gene resulted in increased activity with both explosives.

Morganella morganii nitrofurazone-resistant mutants showed neither TNT nor RDX nitroreductase activity. Mutants of $E$. coli resistant to the broad spectrum antibiotic nitrofurazone had also lost type I nitroreductase activity (McCalla et al. 1970; Whiteway et al. 1998). Consequently, we isolated UV-induced nitrofurazone-resistant mutants of $M$. morganii to see if either RDX nitroreductase activity or TNT nitroreductase activities were affected. Wild-type M. morganii strain $\mathrm{B} 2$ is effectively killed by $5 \mathrm{mg} \cdot \mathrm{L}^{-1}$ nitrofurazone. A 30-mL culture of $M$. morganii was grown to mid log phase in MM medium (minimal salts from with $40 \mathrm{mM}$ lactate, $10 \mathrm{mM}$ glutamate, $30 \mathrm{mM} \mathrm{NH}_{4}^{+}, 1 \mathrm{mM} \mathrm{L}-$ methionine, $5 \mathrm{~g} \cdot \mathrm{L}^{-1} \mathrm{NaCl}, 1 \mathrm{mg} \cdot \mathrm{L}^{-1}$ pantothenate, and $2 \mathrm{mg} \cdot \mathrm{L}^{-1}$ nicotinate). The culture was harvested by centrifugation and washed twice with $0.85 \% \mathrm{NaCl}$. A $15-\mathrm{mL}$ suspension of bacteria, adjusted to $A_{600}$ of 1.0 (about $1 \times 10^{9}$ cells $\left.\cdot \mathrm{mL}^{-1}\right)$, was placed in a sterile glass petri dish, and exposed to short wavelength $(254 \mathrm{~nm}) \mathrm{UV}$ light for $2 \mathrm{~min}$ (UVP Inc. Model UVG-25, $18 \mathrm{~W}$ at $25 \mathrm{~cm}$ from the plate). This UV exposure killed more than $99 \%$ of the bacteria, as measured by dilution plating. Irradiated cells were diluted 1:50 in fresh MM medium and allowed to grow overnight. These cultures were then plated on NB (Nutrient Broth, Difco) plates with $30 \mathrm{mg} \cdot \mathrm{L}^{-1}$ nitrofurazone (NF) in the 
Table 3. Nitrofurazone resistance results in a loss of both TNT and RDX nitroreductase activities.

\begin{tabular}{|c|c|c|c|}
\hline \multirow[b]{2}{*}{ M. morganii strain } & \multicolumn{2}{|c|}{$\begin{array}{c}\% \text { Nitroreductase } \\
\text { activity with }\end{array}$} & \multirow{2}{*}{$\begin{array}{l}\text { Inhibiting concentration } \\
\text { of nitrofurazone }{ }^{c}\end{array}$} \\
\hline & $\mathrm{TNT}^{a}$ & $\mathrm{RDX}^{b}$ & \\
\hline B2 (wild type) & 100 & 100 & 5 \\
\hline B2M10 & $<1$ & $<1$ & 50 \\
\hline B2M13 & $<1$ & $<1$ & 50 \\
\hline
\end{tabular}

${ }^{a}$ Percent of TNT nitroreductase activity compared to strain B2, as measured by NADPH oxidation with cell free extracts.

${ }^{b}$ Percent of RDX nitroreductase activity compared to strain B2 as measured by RDX disappearance in the first 4 days of cell culturing.

${ }^{c}$ Minimum inhibitory concentration of nitrofurazone $\left(\mathrm{mg} \cdot \mathrm{L}^{-1}\right)$. Reduction of nitrofurazone results in the production of toxic compounds.

solid medium. Nitrofurazone-resistant colonies appeared at a frequency of about $1 \times 10^{-7}$. After incubating two days, 4 colonies each were picked from two independent experiments, and restreaked for purity. Two representative mutant strains (B2M10, B2M13) were assayed for both TNT and RDX nitroreductase activity. Strains B2M10 and B2M13 had no detectable TNT nitroreductase activity (less than $1 \%$ of the wild type strain) and no detectable RDX nitroreductase activity (Table 3 ). Both mutant strains grew on MM medium, exhibiting the same nutritional requirements as the wild type strain. However, both strains lost both TNT and RDX nitroreductase activities (Table 3). This indicates that the loss of a single gene resulted in the loss of both activities.

Both RDX and TNT nitroreductase activities were detected in whole cells of E. cloacae, isolated for its TNT nitroreductase activity (Bryant and DeLuca 1991) and in M. morganii strain B2, isolated for the ability to degrade the nitramine explosives RDX and HMX (Kitts et al. 1994). The ratio of TNT/RDX nitroreductase activity was similar for both E. cloacae and M. morganii, indicating a similar mechanism of nitroreduction in both strains (Table 1). The purified type I nitroreductase from E. cloacae strain 96-3 was active with RDX, at a ratio of TNT/RDX activity similar to what was seen in whole cells. Induction of the E. cloacae nitroreductase gene in $E$. coli resulted in simultaneous increases in TNT and RDX nitroreductase activities. Finally, nitrofurazone-resistant mutants of $M$. morganii had lost nitroreductase activity with TNT and RDX. These results clearly show that in each strain, TNT and RDX nitroreduction was performed by the same nitroreductase enzyme. Furthermore, the results indicate these activities were mediated by type I oxygen-insensitive nitroreductases in both strains.

However, in many studies that use conditions favoring fast growing, heterotrophic, facultative anaerobes like the enteric bacteria, TNT is reduced by either aerobic or anaerobic cultures, while RDX is only reduced by anaerobic cultures (Isbister et al. 1982; Kaplan 1990; Kitts et al. 1994; McCormick et al. 1981; McCormick et al. 1984; Spanggord et al. 1983). Aerobic cultures of M. morganii and E. cloacae reduced measurable amounts of TNT in vivo, but did not reduce measurable amounts of RDX. This observation creates the impression that an RDX nitroreductase would be a type
II oxygen sensitive enzyme, and furthermore that it would not be the same enzyme that reduces TNT. However, we showed in this study that type I oxygen-insensitive nitroreductases can use RDX as a substrate. We also showed that the previously purified type I nitroreductase of E. cloacae reduced RDX in an aerobic in vitro assay. Why then is RDX not reduced by aerobic cultures of these organisms? Intriguingly, organisms isolated for the capacity to aerobically degrade RDX do not use a nitrogroup reduction pathway (Binks et al. 1995; Coleman et al. 1998). It is tempting to speculate on the role of intracellular reductant concentrations in this case, since anaerobic cells with plenty of carbon to oxidize could be expected to have much higher concentrations of reductant $(\mathrm{NAD}(\mathrm{P}) \mathrm{H})$ than aerobic cells. A definitive answer to this question awaits a more detailed kinetic study of the type I nitroreductase enzymes with both explosives as substrates.

\section{Acknowledgements}

Sincere thanks are due to Dr. Anne-Francis Miller (Department of Chemistry, Johns Hopkins University) and Ronald L. Koder Jr. (Institute for Biophysical Research on Macromolecular Assemblies, Johns Hopkins University) for supplying us with a sample of purified E. cloacae type I nitroreductase, and to Dr. Chris Bryant (Armor Pharmaceuticals, Chicago) for a culture of $E$. coli strain TB1. The generosity and openness of these individuals is a great credit to them and has reaffirmed my trust in the scientific community as a whole.

\section{References}

Alvarez, M.A., Kitts, C.L., Botsford, J.L., and Unkefer, P.J. 1995. Pseudomonas aeruginosa strain MA01 aerobically metabolizes the aminodinitrotoluenes produced by of 2,4,6-trinitrotoluene nitro group reduction. Can. J. Microbiol. 41: 984-91.

Beardsmore, A.J., Aperghis, P.N.G., and Quayle, J.R. 1982. Characterization of the assimilatory and dissimilatory pathways of carbon metabolism during growth of Methylophilus methylotrophus on methanol. J. Gen. Microbiol. 128: 1423-1439.

Binks, P., Nicklin, S., and Bruce, N.C. 1995. Degradation of Hexahydro-1,3,5-Trinitro-1,3,5-Triazine (RDX) by Stenotrophomonas maltophilia PB1. Appl. Environ. Microbiol. 61: 13181322.

Brenner, D.J. 1984. Family I. Enterobacteriaceae. In Bergey's manual of systematic bacteriology, Vol. 1. Edited by N.R. Krieg and J.G. Holt. Williams and Wilkins Co., Philadelphia, Pa.

Bryant, C., and DeLuca, M. 1991. Purification and characterization of an oxygen-insensitive $\mathrm{NAD}(\mathrm{P}) \mathrm{H}$ nitroreductase from Enterobacter cloacae. J. Biol. Chem. 266: 4119-4125.

Bryant, C., Hubbard, L., and McElroy, W.D. 1991. Cloning, nucleotide sequence, and expression of the nitroreductase gene from Enterobacter cloacae. J. Biol. Chem. 266: 4126-4130.

Cartwright, N.J., and Cain, R.B. 1959. Bacterial degradation of the nitrobenzoic acids. 2. Reduction of the nitro group. Biochem. J. 73: 305-314.

Coleman, N.V., Nelson, D.R., and Duxbury, T. 1998. Aerobic biodegradation of Hexahydro-1,3,5-Trinitro-1,3,5-Triazine (RDX) as a nitrogen source by a Rhodococcus sp., strain DN22. Soil Biol. Biochem. 30: 1159-67. 
Einistö, P., Watanabe, M., Ishidate, M., and Nohmi, T. 1991. Mutagenicity of 30 chemicals in Salmonella typhimurium strains possessing different nitroreductase or $O$-acetyltransferase activities. Mutat. Res. 259: 95-102.

Hartter, D.R. 1985. The use and importance of nitroaromatic chemicals in the chemical industry. In Toxicity of nitroaromatic compounds. Chemical industry institute of toxicology series. Edited by D.E. Rickert. Hemisphere Publishing, New York. pp. 1-13.

Ingram, J.L., Maaloe, O., and Neidhardt, F.C. 1983. Growth of the bacterial cell. Sinauer Associates, Inc. Sunderland Mass. p. 3.

Isbister, J.D., R.C. Doyle, and J.F. Kitchens. 1982. Engineering and development support of general decon technology for the U.S. Army's installation restoration program. Task 11. Composting of explosives. Report DAAK11-80-C-0027. U. S. Army Toxic and Hazardous Materials Agency.

Kaplan, D.L. 1990. Biotransformation pathways of hazardous energetic organo-nitro compounds. In Biotechnology and biodegradation. Advances in biotechnology series Vol. 4. Edited by D. Kamely, A. Chakrabarty, and G.S. Omenn. Portfolio Publishing Co., Texas. pp. 155-181.

Kinouchi, T., and Ohnishi, Y. 1983. Purification and characterization of 1-nitropyrene nitroreductases from Bacteroides fragilis. Appl. Environ. Microbiol. 46: 596-604.

Kitts, C.L., Cunningham, D.P., and Unkefer, P.J. 1994. Isolation of three hexahydro-1,3,5-trinitro-1,3,5-triazine degrading species of the family Enterobateriacaea from nitramine explosivescontaminated soil. Appl. Environ. Microbiol. 60: 4608-4611.

Liu, D., Thomson, K., and Anderson, A.C. 1984. Identification of nitroso compounds from biotransformation of 2,4-dinitrotoluene. Appl. Environ. Microbiol. 47: 1295-1298.

McCalla, D.R., Reuvers, A., and Kaiser, C. 1970. Mode of action of nitrofurazone. J. Bacteriol. 104: 1126-1134.

McCormick, N.G., Cornell, J.H., and Kaplan, A.M. 1981. Biodegradation of hexahydro-1,3,5-trinitro-1,3,5-triazine. Appl. Environ. Microbiol. 42: 817-823.

McCormick, N.G., Cornell, J.H., and Kaplan, A.M. 1984. The anaerobic biotransformation of RDX, HMX and their acetylated derivatives. AD Report No. A149464. U. S. Army Natick Research and Development Center. Natick, Mass.

McCormick, N.G., Herry, F.E., and Levinson, H.S. 1976. Microbial transformation of 2,4,6-trinitrotoluene and other nitroaromatic compounds. Appl. Environ. Microbiol. 31: 949-957.

Mori, M., Miyahara, T., Hasegawa, Y., Kudo, Y., and Kozuka, H. 1984. Metabolism of dinitrotoluene isomers by Escherichia coli isolated from human intestine. Chem. Pharm. Bull. 32: 4070-4075.

Peterson, F.J., R. Mason, R.P., Hovsepian, J., and Holtzman, J.L. 1979. Oxygen-sensitive and -insensitive nitroreduction by Escherichia coli and rat hepatic microsomes. J. Biol. Chem. 254: 4009-4014.

Schackmann, A., and Müller, R.. 1991. Reduction of nitroaromatic compounds by different Pseudomonas species under aerobic conditions. Appl. Microbiol. Biotechnol. 34: 809-813.

Schenzle, A., Lenke, H., Spain, J.C., Knackmuss, H. 1999. Chemoselective nitro group reduction and reductive dechlorination initiate degredation of 2-chloro-5-nitrophenol by Ralstonia eutropha JMP134. Appl. Environ. Microbiol. 65: 2317-2323.

Spanggord, R.J., Mabey, W.R., Chou, T.-W., Lee, S., Tse, D.S., and Mill, T. 1983. Environmental fate studies of HMX. Phase II Detailed Studies. Final Report. SRI International, Menlo Park, Calif. Contract No. DAMD 17-82-C-2100 U. S. Army Medical Research and Development Command, Fort Detrick, Frederick, Md.

Tabor, S., and Richardson, C.C. 1985. A bacteriophage T7 RNA polymerase/promoter system for controlled exclusive expression of specific genes. Proc. Natl. Acad. Sci. U.S.A. 82: 1074 1078 .

Wenzhong, L., Ping, Y., and Uanxi, Y. 1987. Properties of TNTdegrading enzymes in intact cells of Citrobacter freundii. ACTA Microbiol. Sin. 27: 257-263.

Whiteway, J., Koziarz, P., Veall, J., Sandhu, N., Kumar, P., Hoecher, B., and Lambert, I.B. 1998. Oxygen-insensitive nitroreductases: analysis of the roles of $n f_{s A} A$ and $n f_{s} B$ in development of resistance to 5-nitrofuran derivatives in Echerichia coli. J. Bacteriol. 180: 5529-5539. 